\title{
Histological studies on flower abortion in olive cultivars
}

\author{
E. S. HEGAZI ${ }^{1}$, G. R. STINO ${ }^{1}$, S. T. BOULOS ${ }^{2}$ \\ Faculty of Agriculture Cairo University, Egypt \\ ${ }^{1}$ Department of Horticulture, Faculty of Agriculture, Cairo University; ${ }^{2}$ Plant Research Laboratory, \\ Dessert Institute, Cairo \\ (Received: September 9, 1980)
}

\begin{abstract}
Two main categories of olive flowers were characterized. The first by presence of normal gynoecium and the other by the presence of rudimentary gynoecium. Complete flowers differed in shape of ovaries, style length, shape of stigma and density of hairs covering the stigma. Three types of aborted flowers were observed. The first type could be detected by lack of ovule integuments. The second by undevelopment of the style, outer tissues of the ovary and of the ovules, while the third comprised flowers of completely undeveloped female organs. No correlation existed between pistil abortion and the viability of pollen grains. Four groups of pollen grains regarding their stainability and three groups according to their shape were detected.
\end{abstract}

\section{INTRODUCTION}

Many olive trees fail to set satisfactory yield due to pistil abortion resulting in lack of sufficient numbers of perfect flowers ( $\mathrm{H}$ a $\mathrm{r} \mathrm{m}$ a $\mathrm{n} \mathrm{n,} \mathrm{1950;}$ R u gi e r i, 1950; H e g a z i, 1970, 1973). M or e t t i n i (1951) found that each variety showed a specific percentage of abortion under normal circumstances. Environmental factors and cultural practices were also found to have significant effect on this phenomenon ( $\mathrm{H} \mathrm{a} \mathrm{r} \mathrm{t} \mathrm{m} \mathrm{a} \mathrm{n} \mathrm{n,} \mathrm{1950;}$ $\mathrm{H}$ a $\mathrm{rtm}$ a $\mathrm{n}$ and $\mathrm{H}$ of $\mathrm{fm} \mathrm{a} \mathrm{n}, 1953$; $\mathrm{Ur} \mathrm{i} \mathrm{u}, 1956)$. The major interest of present study was to investigate the morphology and histology of flowers in different olive cultivars.

\section{MATERIAL AND METHODS}

The present study was conducted on flowers of 20 olive cultivars imported to Egypt and have been grown in the experimental orchard of the Faculty of 
Agriculture, Cairo University, since 1966. The study was conducted to determine variable types of flowers, differences in structure of gynoecia, cases and stages of pistil abortion of extremal cultivars. The following technique was persuaded. Flower panicles borne on one-year-old shoots of determined cultivars were selected at ballon stage, prior to flower opening ( $\mathrm{H} \mathrm{e} \mathrm{g} \mathrm{a} \mathrm{z}$ i, 1970). They were killed and fixed immediately in FAE ( $70 \%$ ). Dehydration was achieved by normal butyl alcohol according to $J$ o h a $\mathrm{n}$ s e $\mathrm{n}$ (1940). Infiltration and embedding were followed by using parafin wax of $54-56^{\circ} \mathrm{C} \mathrm{M}$. P. Longitudinal sections were cut at $12 \mu \mathrm{m}$ thickness. Sections were stained by crystal violet and erythrosine (Jackson, 1926) and microscopically examined. Acetocarmine technique, according to J,o h a $\mathrm{n}$ s e $\mathrm{n}$ (1940) was used to determine the stainability of pollen grains for each studied cultivar.

\section{RESULTS}

No significant differences could be observed concerning the calyx, corrolla or the stamen of different cultivars. The main differences were observed in morphology and anatomy of the female organs. The female organ of the olive flowers is composed of a single superior ovary of two celled carpels, each contains two ovules. The carpels are united from base to apex and forming a gynoecium with a single ovary, style and stigma. It had been observed that the style is composed of a transmitting tissue starting from the stigma and extending downward, till reaching the ovules (Fig. 2, 4). The stigma which is always covered with unicellular hairs differs according to the studied cultivars. Types of flowers in the cultivars under investigation can be classified in two main categories - a complete or normal flowers (perfect), and incomplete or abnormal flowers (aborted).

In complete flowers, different organs of flowers developed normally. These flowers could be classified to the following types according to the shape of the ovary: oblong or spherical.

At the same time, it was observed that the surface of the ovary might be classified according to one of three types: ovary having smooth surface (Fig. 6), deeply waved with deep grooves (Fig. 5) and intermediately waved (Fig. 4).

These types resulted in giving variability in fruit shapes at the fruiting period. Flowers also differed according to the style and stigma. The style might be short (Fig. 5) or long (Fig. 1). In all types of style a short stylar canal could be observed near the ovary (Fig. 2), while the main tissue of the style is composed of transmitting tissue which provides a nutrient substrate which aids the pollen tube to grow through it. The stigma, as mentioned before, is covered with unicellular hairs, these hairs might grow on the whole surface and give the shape of a cup and the stigma in this case covers about half of the style (Fig. 3). In some cases, the stigma might cover only one third of the style as shown in Fig. (4). The density of 
the hairs may be high as shown in the types illustrated in Fig. 3, or may be normal as in Fig. 4. The stigma also may not cover the whole surface of the style but it covers only one side as shown in Figs. 1, 6. It could be emphasized that abnormal flowers could be considered as staminate flowers where the anthers developed normally and produced normal mature pollen grains. The undeveloped tissues occurred at different parts of the pistil, these results of variable degrees of abortion and could be classified into three types:

the ovary develops normally and the ovules develop to a certain stage and no integuments could be observed while the style is aborted (Fig. 7),

both the style and the outer tissues of the ovary do not develop but the ovules develop primitively but do not reach a further step (Fig. 8),

the female organs cease to develop and all organs remain rudimentary (Fig. 9).

The pollen grains of the studied cultivars are small, their diameter $15.9 \times 17.0$ $\mu \mathrm{m}$ and are considered as airborne pollen grains. The grain bore a medium thickness exine with rather thin entine. The shape of the pollens are rather oblate spheroidal with three furrows. At the same flowers many degrees of development of pollens might be observed as shown in Fig. 10. The shape classes which might be observed are the prolate spheroidal (Fig. 10a), oblate spheroidal (Fig. 10b), and tricolporate (Fig. 10c).

The stainability of the grains might differ according to the degree of development of the grain and could be classified to four groups:

deeply stained group and are mainly of the prolate and oblate spheroidal shape (Fig. 11a),

Ta ble 1

Stainability of pollen grains

\begin{tabular}{lclc}
\hline \multicolumn{1}{c}{ Cultivars } & $\begin{array}{c}\text { Stainable } \\
\text { grains } \\
\%\end{array}$ & \multicolumn{1}{c}{ Cultivars } & $\begin{array}{c}\text { Stainable } \\
\text { grains } \\
\%\end{array}$ \\
\hline 'Coratina 1' & 33.6 & 'Gordal' & $85.3^{\mathrm{ab}}$ \\
'Arbequin' & $62.4^{\mathrm{a}}$ & 'Coratina 2' & $88.7^{\mathrm{ab}}$ \\
'Chemlali 2' & $70.3^{\mathrm{ab}}$ & 'Chemlali T' & $89.1^{\mathrm{ab}}$ \\
'Mossolati' & $71.0^{\mathrm{ab}}$ & 'Negral' & $89.7^{\mathrm{ab}}$ \\
'Ouslati' & $71.9^{\mathrm{ab}}$ & 'Blanquetta' & $93.2^{\mathrm{b}}$ \\
'Chemlali 1' & $73.6^{\mathrm{ab}}$ & 'Serrana' & $94.8^{\mathrm{b}}$ \\
'Chemlali 3' & $76.3^{\mathrm{ab}}$ & 'Changlot real' & $94.9 \mathrm{~b}$ \\
'Villa longa' & $82.0^{\mathrm{ab}}$ & 'Frantoio' & $94.9^{\mathrm{b}}$ \\
'Enduri' & $83.5^{\mathrm{ab}}$ & 'Picual' & $95.1^{\mathrm{b}}$ \\
'Sevillano' & $84.0^{\mathrm{ab}}$ & & \\
\hline
\end{tabular}

Any two means followed by the same letter are not significantly different from each other at 0.05 level of probability (D u n c a n, 1955). 
lightly stained group and of nearly the tricolporate shape and sometimes of the prolate spheroidal shape (Fig. 11b),

unstained group having a diameter nearly as those of the stained group (Fig. 11c),

unstained group, where those were very small and undeveloped (malformed), (Fig. 11d).

Results concerning the stainability of pollen grains for the studied cultivars are presented in Table 1. It is obvious that 'Coratina 1' cv. had the lowest percentage of stainable pollen grains (33.6) percent, while 'Picual' cv. had the highest (95.0) percent. Different cultivars, in general, could be classified according to this percentage as follows: 'Coratina 1', contained less than 40 percent stainable pollen grains, whereas 'Arbequin' had less than 70 percent. The third class could be represented by 'Chemlali 2', 'Mossolati', 'Ouslati', 'Chemlali 1', 'Chemlali 3', which range from 70 to 80 percent. The fourth group contained cultivars of stainable grains from 80 to 90 percent such as 'Villa Longa', 'Enduri', 'Sevillano', 'Gordal', 'Coratina 2', 'Chemlali T', and 'Negral', 'Blanquetta', 'Serrana', 'Changlot real', 'Frantoio' and 'Picual' occupied the fifth group with more than $90 \%$ of stainable grains.

\section{DISCUSSION}

The general anatomy of the gynoecia of the studied cultivars coincides with what has been described in the literature ( $\mathrm{H}$ a $\mathrm{r} \mathrm{m}$ a $\mathrm{n} \mathrm{n}, 1949$; $\mathrm{M}$ o r et t i n i, 1951; C h a n d l e r, 1958; U r i u, 1959). Moreover, it was clearly noticed that the style was composed of a transmitting tissue starting from the stigma and extending downward, and was connected with a short stylar canal at the base of the style reaching the ovules. Two types of flowers, according to the presence of the gynoecium could be noticed, perfect or complete flowers were characterized by the presence of a normal gynoecium while abnormal or aborted flowers were characterized by rudimentary gynoecium. The complete flowers contained an oblong or spherical ovary. The outer surface of the ovary might be smooth, deeply or intermediately waved. The style might be short or ratther long. The stigma was covered by unicellular hairs differing in density and the area which they cover. Variable degress of pistil abortion could be noticed in aborted flowers. In certain flowers evidence of abortion was detected by lack of ovule integuments. Another type of abortion was characterized by the undevelopment of the ovules themselves. The third type comprised flowers of completely undeveloped female organs.

A complete study of the pollen grains morphology is given in the results. It could be emphasized that four groups of pollen grains could be detected. These groups were characterized by the following deeply stained of prolate or oblate spheroidal shape, lightly stained and tricolporate in shape, unstained having a 

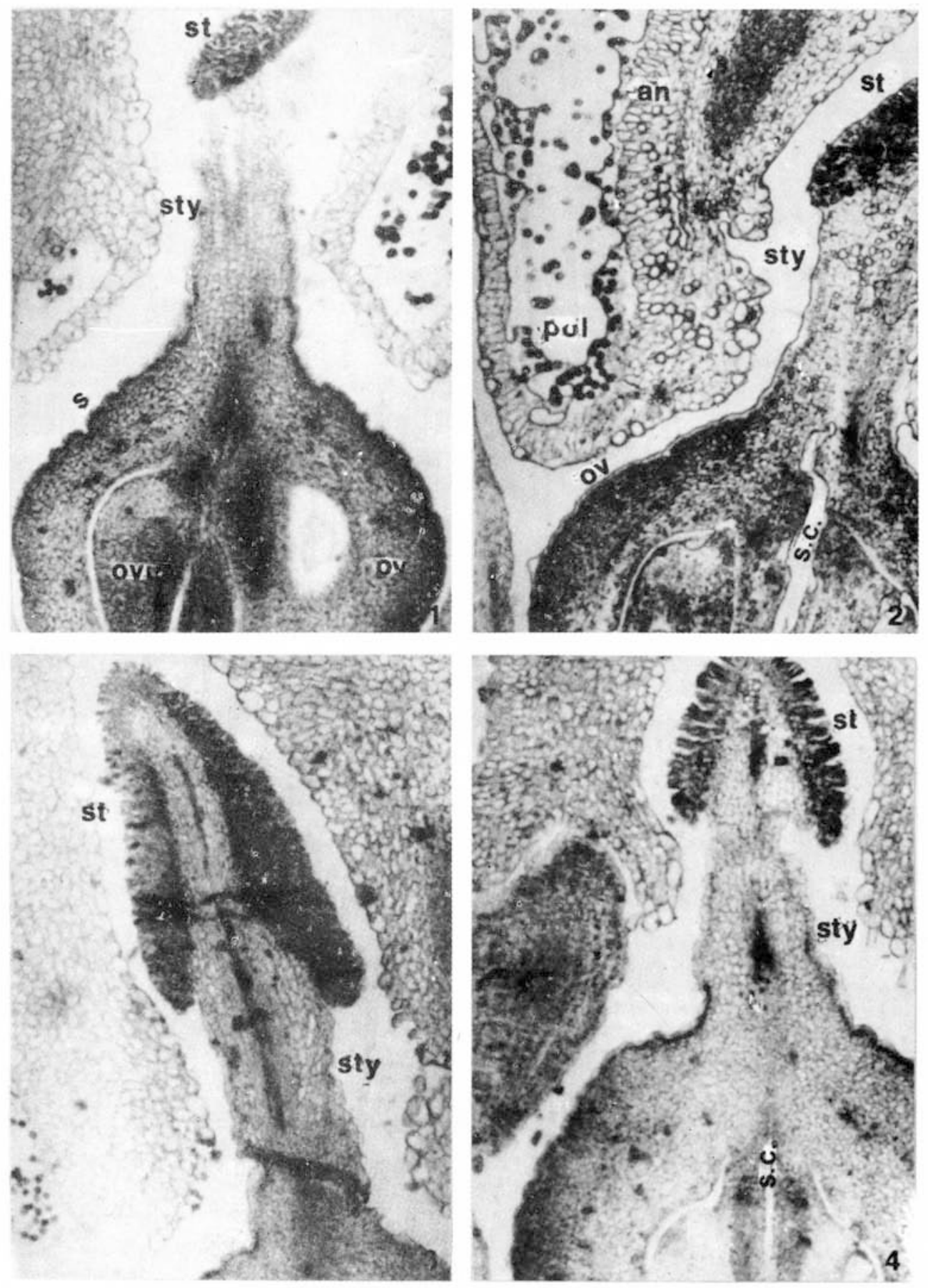

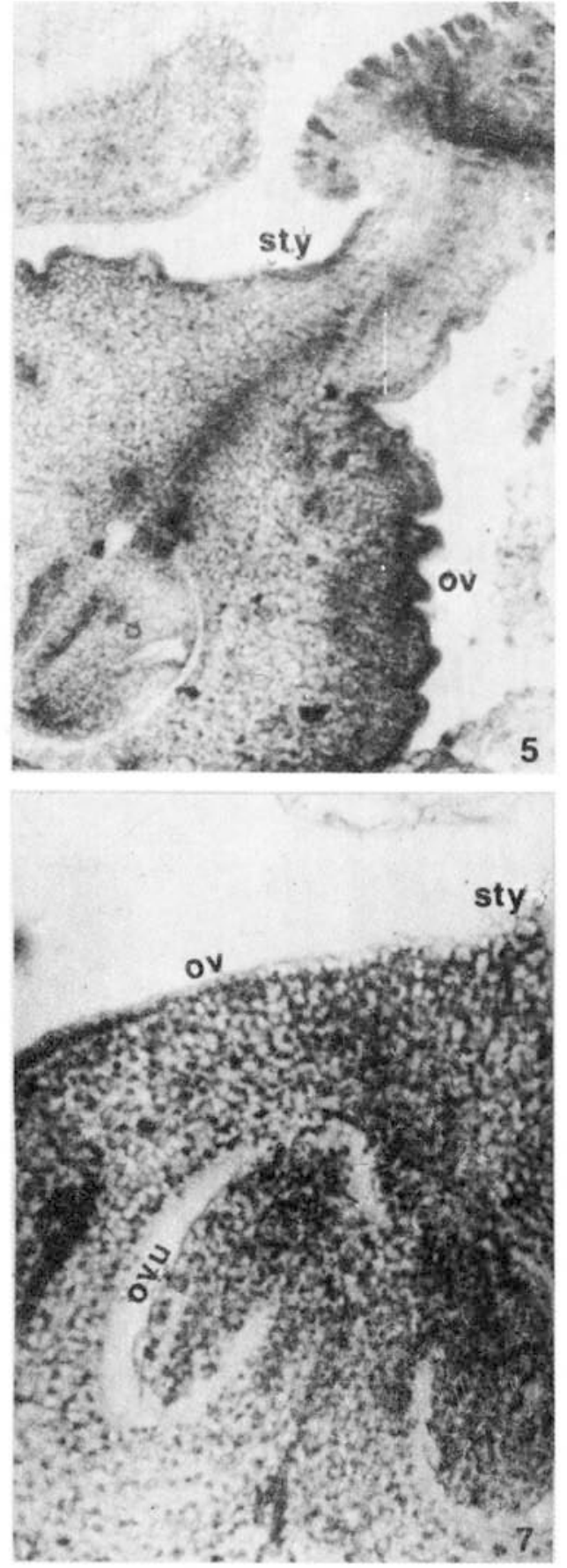
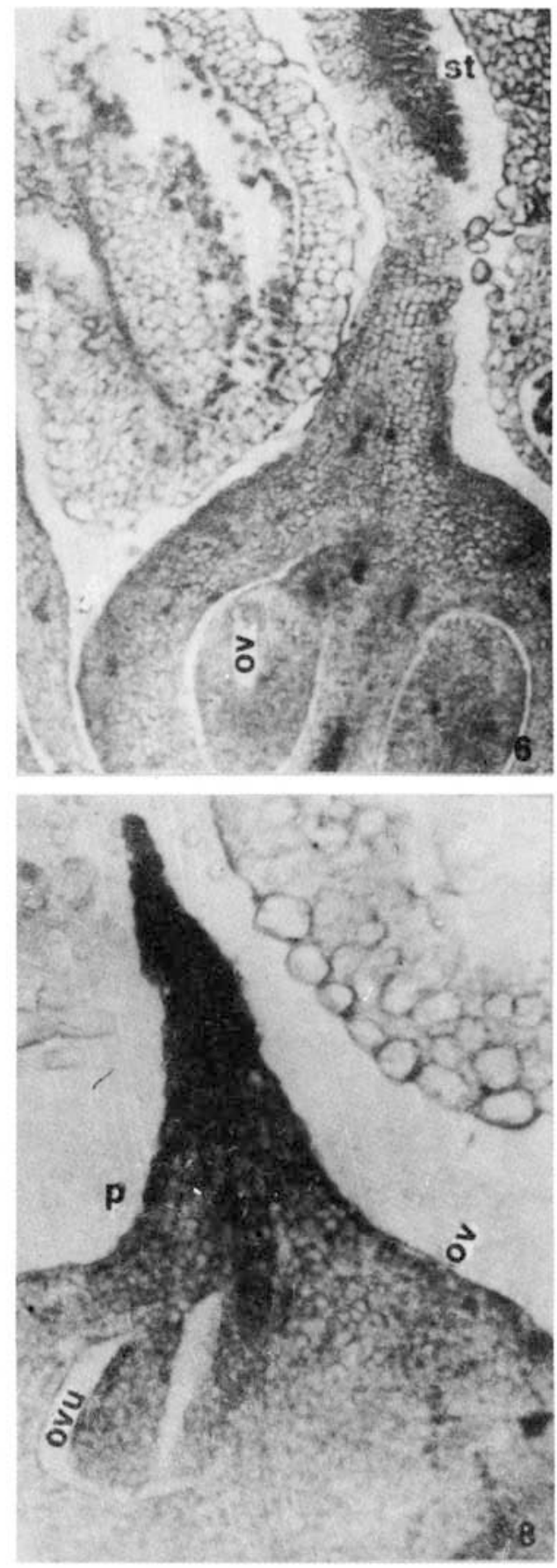

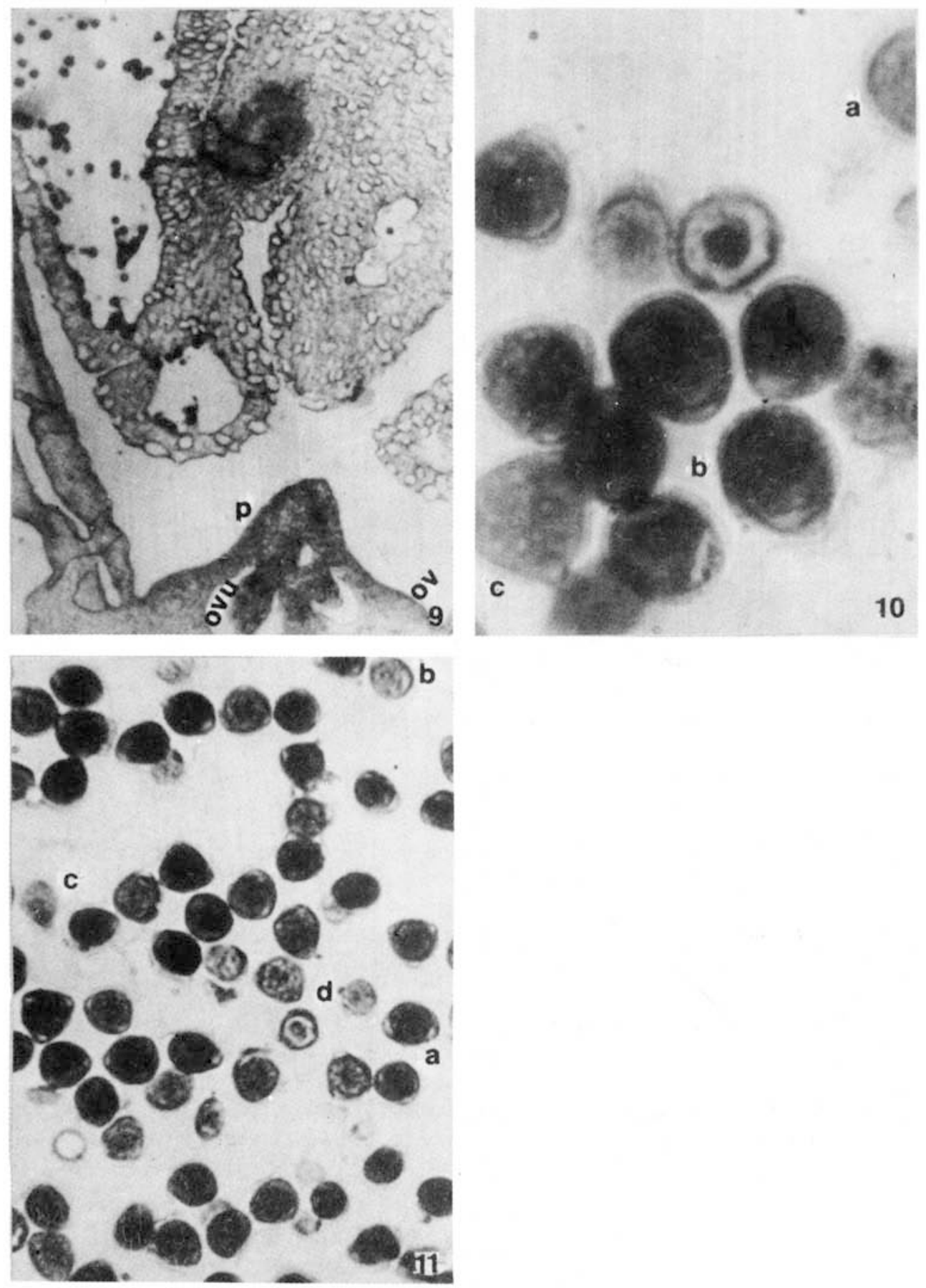
Fig. 1. Longitudinal section (L. S.) through the pistil showing spherical ovary (ov), wavy surface of the ovary (s), the ovules (ovu) developed normally, long style (sty), stigma (st) covering one side of the style, $(\times 63)$

Fig. 2. L. S. through the pistil showing short style (sty), one sided stigma (st), the stylar canal evident near the base (s. c.), spherical ovary (ov), pollen grains (pol) in the anther (an), $(\times 63)$

Fig. 3. L. S. through the pistil showing the stigma (st) covered with dense hairs and overlaying half of the style $(\times 63)$

Fig. 4. L. S. through the pistil showing cup shape of stigma (st), normal hairs covering stigma, short style (sty), the styler canal (s. c.), transmitting tissue (t.t.), ) $\times 63$ )

Fig. 5. L. S. through the pistil showing the surface of the ovary accutely waved with deep grooves (ov), short style (sty), $(\times 63)$

Fig. 6. L. S. through the pistil showing smooth surface of the ovary (ov), one sided stigma (st), $(\times 63)$

Fig. 7. L. S. through aborted pistil (Type I) showing normal ovary (ov), ovule developed to a certain degree (ovu), rudimentary style $($ sty $),(\times 158.7)$

Fig. 8. L. S. through aborted pistil (Type II) showing reduced pistil (p), patrially developed ovary (ov), reduced ovules (ovu), $(\times 158.7)$

Fig. 9. L. S. aborted flower (Type III) showing rudimentary pistil (p), undeveloped ovary (ov), rudimentary ovules (ovu), $(\times 63)$

Fig. 10: Different types of pollen grains, a - prolate spheroidal, b - oblate spheroidal, c - tricolporate $(\times 1008)$

Fig. 11. Stainability of poller grains, a - deeply stained, b - lightly stained, c - unstained with normal diameter, $\mathbf{d}-$ unstained with small diameter (malformed), $(\times 403.2)$ 
diameter nearly as those of the stained group and unstained characterized by being very small and undeveloped (malformed). According to the study it can be stated that no correlation existed between pistil abortion and the viability of pollen grains.

\section{REFERENCES}

C h a n d 1 e r W. H., 1958. Evergreen orchards. Henry Kempton, London, W. C. L. Lea and Febiger.

H a $\mathrm{r} \mathrm{t} \mathrm{m}$ a $\mathrm{n} \mathrm{H}$. T., 1950. The effect of girdling on flower type, fruit set and yields in olives. Proc. Amer. Soc. Hort. Sci. 56: 217-26.

H a r t m a n n H. T., H of $\mathrm{f} m$ a $\mathrm{n}$ R. M., 1953. Olive fruiting behaviour. Calif. Agric. 1(2) 9-10. $\mathrm{H} \mathrm{e} \mathrm{g} \mathrm{a} \mathrm{z} \mathrm{i} \mathrm{E.} \mathrm{S.,} \mathrm{1970.} \mathrm{Studies} \mathrm{on} \mathrm{growth,} \mathrm{flowering} \mathrm{and} \mathrm{fruiting} \mathrm{of} \mathrm{some} \mathrm{new} \mathrm{olive} \mathrm{seedling} \mathrm{strains.}$ M. Sc. Fac. Agric. Cairo Univ.

$\mathrm{H}$ e g a $\mathrm{z}$ i E.S., 1973. Sex expression in certain olive cultivars as affected by some growth regulators.

Ph. D. Diss. Fac. Agric. Cairo Univ.

J a c k s o n G., 1926. Crystal violet and erythrosine in plant anatomy. Stain. Tech. 1: 33-34.

J o h a n s e n D. A., 1940. Plant Microtechnique. McGrow Hill Book Co. Inc. New York.

M o r e t t i n i A., 1951. A further contribution to the study of ovary abortion in olive. Ann. Sper. Agrar. 57: 309-29.

R u g i e $\mathbf{r}$ i G., 1950. Notes on recent studies and investigations on the floral biology of the olive. Suppl. Ann. Sper. Agrar. 4 (N. S.), 2.

U r i u K., 1959. Periods of pistil abortion in the development of the olive flower. Proc. Amer. Soc. Hort. Sci. 73: 194-202.

\section{Badania histologiczne nad niedorozwojem kwiatów u odmian uprawnych oliwki}

\section{St r e s z c z e n i e}

Scharakteryzowano dwa główne rodzaje kwiatów oliwki. Pierwszy posiada normalne słupkowie, a w drugim słupkowie jest szczątkowe. Normalne kwiaty odróżniają się ksztaltem zalążni, długością szyjki słupka, kształtem znamienia i gęstością włosków pokrywających znamię. Wyodrębniono trzy typy niedorozwoju kwiatów. W pierwszym typie zalążki nie posiadają osłonek w drugim występuje niedorozwój szyjki słupka i zewnętrznych tkanek zalążni i zalążków, podczas gdy w trzecim typie występują kwiaty o całkowicie nierozwiniętych organach żeńskich. Nie znaleziono korelacji między niedorozwojem słupkowia a żywotnością pyłku. Opisano cztery typy ziaren pyłku na podstawie ich barwienia i trzy grupy na podstawie ich kształtu. 